$\begin{array}{r}\text { Volume and Issues Obtainable at Center for Sustainability Research and Consultancy } \\ \text { Journal of Business and Social Review in Emerging Economies } \\ \text { ISSN: 2519-089X (E): 2519-0326 } \\ \text { Volume 6: No. 4, December } 2020 \\ \text { JSRᄃ } \\ \text { Journal homepage: www.publishing.globalcsrc.org/jbsee } \\ \hline\end{array}$

\title{
The Socio-Political Obstacles behind the Scanty Political Participation of Women Parliamentarians
}

\begin{tabular}{|c|c|}
\hline \multicolumn{2}{|c|}{$\begin{array}{c}{ }^{1} \text { Hamida Bibi } \\
{ }^{1} \text { Lecturer in Bacha Khan Medical College Mardan, Khyber Medical University Peshawar, KP, Pakistan }\end{array}$} \\
\hline ARTICLE DETAILS & ABSTRACT \\
\hline $\begin{array}{l}\text { History } \\
\text { Revised format: November } \\
2020 \\
\text { Available Online: December } \\
2020\end{array}$ & $\begin{array}{l}\text { The current study was conducted to indicate the numerous factors } \\
\text { active behind the scanty political participation of women } \\
\text { parliamentarians in parliamentary processions. For the collection of } \\
\text { data for the current study, women parliamentarians and women's }\end{array}$ \\
\hline $\begin{array}{lr}\text { Keywords } & \\
\text { Politics, } & \text { Participation, } \\
\text { Patriarchy, } & \text { Parliament, } \\
\text { Women, } & \\
\end{array}$ & $\begin{array}{l}\text { rights activists were interviewed. Semi-structured in-depth interview } \\
\text { was used as research tool for data collection. For the analysis of data, } \\
\text { the tool of Thematic Analysis, developed by Braun and Clarke } \\
\text { (2015), was used. The findings of the study highlight some socio- }\end{array}$ \\
\hline $\begin{array}{l}\text { JEL Classification } \\
M 10, M 14\end{array}$ & $\begin{array}{l}\text { political obstacles such as the lack of educational adeptness and } \\
\text { political shrewdness, representing minority or reserved quota, the } \\
\text { patriarchal and male-dominant model of politics, party politics, etc. } \\
\text { are impeding the effective participation of women parliamentarians. } \\
\text { All this has upset to work freely and securely dissuading women's } \\
\text { political achievements. In the light of the findings of the study, the } \\
\text { author recommends society changing its attitude towards women } \\
\text { politics. Women participation in politics ought to be encouraged at } \\
\text { the cost of the abolition of patriarchy in politics. The government } \\
\text { should help women parliamentarians. In order to be adept and astute, } \\
\text { special trainings and sessions shall be arranged for women } \\
\text { parliamentarians. Political parties should clearly policy in this regard } \\
\text { avoiding party politics and the supremacy of some political figures. }\end{array}$ \\
\hline
\end{tabular}

OPEN ACCESS

(C) 2020 Center for Sustainability Research and Consultancy Pakistan under a Creative Commons Attribution-NonCommercial-ShareAlike 4.0

Corresponding author's email address: tazkiasayed@ gmail.com

Recommended citation: BiBi, H. (2020). The Socio-Political Obstacles behind the Scanty Political Participation of Women Parliamentarians. Journal of Business and Social Review in Emerging Economies, 6(4), 1457-1461

\section{Introduction}

Political participation as a voter entails a variety of activities, viz. political thinking, political propagation, political campaigning, multitudes' mobilization and political proselytization, funds' donation, joining political parties, and, above all, vote cast in an election. (Teorell, Torcal \& Montero, 2007). All this is performed to make a hey in the formation of public policies. On the contrary, political participation - as a parliamentarian - means presenting rhetoric on issues of public interest, initiating bills, questioning and raising objections on bills, moving resolutions, forwarding motions, calls on the government, petitions, etc. on the floor of parliament. 
Since the inception of the organized-cum-political human society and parliamentary government, despite an immensurable swell in their populace, women's political participation — both as parliamentarians and voters - is minimal (Lawless \& Fox, 2001). According to Zardari (2018), in 2015, around the world, only $22.1 \%$ women became part of parliament. It took immensurable efforts on behalf of women populace to achieve suffrage - the right to vote. Philosophers, feminists, and women rights activists have time and again reiterated the significance of women's participation in politics, government and policy making for the mitigation of their grievances in numerous spheres of life. Different socioeconomic-cum-statal factors impede women's political participation. The socio-cultural division and dissemination of power, resources and activities between men and women is uneven and partial tilted towards men. This predilection has anchored women's mobility, education, political participation and economic activities ensuing women's dependency and men's power in social, political, and economic arenas (Paxton, Hughes \& Barnes, 2020).

Contrariwise, besides these frequent impediments obstructing women's political participation as voters, sundry encumbrances thwart political participation of women parliamentarians on the floor of assembly. According to Lodhi (2019), lousy education and unripened political skills shrink political participation of women parliamentarians. Quality education, critical thinking, rhetoricalness, and highly ripened-cumpolished political skills are the prerequisites for satisfactory parliamentary performance. Weak selfimage deluges women parliamentarians mulling over their political views, initiations and performances causing the psychiatric condition of inferiority and insignificance.

According to Bano (2009), women's participation in parliamentary affairs is minimal. In the parliamentary session of 2003-2004, women parliamentarians raised only $7 \%$ questions, moved only $12 \%$ resolutions, and passed only $7 \%$ motions out of the total parliamentary questions, resolutions and motions. For the authoress, party politics is all that subdues auspicious participation of women parliamentarians. The stage is always sabotaged by some eminent politicians of a party peripheralizing the women legislators.

A study titled "Sexism, harassment and violence against women in parliaments in Europe" was conducted by Union (2018) to indicate the different impediments women face in parliament. Data for the study was collected from 123 women - 42 parliamentary staff and 81 MPs - from 45 countries in Europe through vis-à-vis interviews. The findings of the study show that out of the 123 women:

1. $85.2 \%$ suffered psychological violence

2. $49.6 \%$ received threats of battering, rape and death

3. $58.2 \%$ received cyber attacks on social media

4. $67.9 \%$ suffered sexist, gendered, stereotypical and abusive comments on their posts on social media

5. $24.7 \%$ suffered sexual harassment

6. $14.8 \%$ suffered physical harassment.

7. $13.5 \%$ faced economic violence - the denial of funds, salaries, allowances, etc.

The melancholic part of the findings were knowing the fact that out of all these anti women crimes, $69.2 \%$ were perpetrated by male parliamentarians. As the repercussions of these crimes, $33.3 \%$ of these women parliamentarians stated that these acts of violence have mitigated our freedom of expression making us more cautious in our parliamentary sayings and doings. Because of the online cyber attacks, women parliamentarians have reduced - if not ended - sharing political ideas and achievements on social media. Above all, these acts of violence have drastically reduced women's participation in parliamentary affairs. Besides affecting women parliamentarians, these acts of violence have discouraged neophyte politicians impeding their way unto politics and parliament. Sexism, harassment and violence against women in parliament are, maximally, politically motivated aimed at mitigating women's political participation. 
According to Khan and Naqvi (2020), after entering into the parliament on reserved seats, women parliamentarians no more remain public representatives. They have to discuss party agendas ignoring women's issues. Party politics hinder women's participation in parliament. Women — those entering into parliament through reserved quota - lack their own constituencies. Henceforth, they are the de facto representatives of political parties not masses. This lack of constituency and entry to the parliament on reserved quota devalues women parliamentarians. Having their own constituencies, the elected parliamentarians, in comparison to those entered to parliament through reserved quota - consider themselves more entitled to participate in parliamentary processions. Besides, Environment for women parliamentarians is hostile and unfriendly. As per statistics by the authoresses, $30 \%$ of women parliamentarians were forced to silence by their male counterparts, $11 \%$ suffered verbal abuse, $6 \%$ received physical threats, and $26 \%$ suffered cyber attacks and defamatory remarks on social media.

In her article titled "Empty women seats in parliament" Zardari (2018) has limelighted the misogynistic demeanor and comportment of our parliament upsetting the participation of women parliamentarians. With the sparse representation of $20 \%$ — inclusive of the $17 \%$ reserved quota - women parliamentarians have invariably tholed misogyny and sexism. The instances are frequent: in 1993, Sheikh Rasheed passed derogatory remarks against Benazir Bhutto. In 2016, Shireen Mizari suffered defamatory remarks from Khwaja Asif. The abusive language of Maulana Fazlu Rehman and his party against PTI women is yet prevalent. All these hardships have barred the active participation of women parliamentarians.

In its study titled "Sexism, harassment, and violence against women parliamentarians", Union (2016) claims psychological, sexual, physical and economic violence against women prevailing in parliaments. The contributing factors are political rivalry, women rights activism, being in opposition, being young, and belonging to minority or reserved quota. These acts of violence have multifaceted impact. Majority of the victims are distressed fearing their safety and that of their family. Besides, these acts of violence impede one's ability to properly execute mandates and openly express opinions drastically mitigating the participation of women parliamentarians in parliamentary processions.

In her study titled "causes of meager participation of women parliamentarians in Khyber Pakhtunkhwa assembly; and the way out", Bibi (2019) has indicated numerous efficacious political, socio-cultural, economic and statal factors extenuating women parliamentarians' active participation in the parliament. The lack of own constituencies, the poor strength of women in parliament, economic dependence and hurdles, socio-cultural constraints, lack of political skills, and the patriarchal-cum-male-dominant politics bar women's active participation in the parliamentary processions.

\section{Objectives of the Study}

Following are the objectives of the study:

1. To know the different socio-political reasons behind the scanty participation of women parliamentarians in the parliamentary processions.

2. To suggest ways to improve the participation of women parliamentarians in the parliamentary processions.

\section{Research Methodology}

The current study was conducted to indicate the numerous factors active behind the scanty political participation of women parliamentarians in parliamentary processions in Khyber Pakhtunkhwa, Pakistan. For the collection of data for the current study, 10 women parliamentarians and women's rights activists were interviewed. Semi-structured in-depth interview was used as research tool for data collection. For the analysis of data, the tool of Thematic Analysis, developed by Braun and Clarke (2015), was used. 


\section{Findings and discussion}

\subsection{Reserved Quota and the Lack of Constituency}

Providing a sense of ownership, reasonability and utility, a constituency is considered a power base for parliamentarians legitimizing their parliamentary endeavors. The findings of the study show that being a minority or a reserved quota parliamentarian bars one's parliamentary participation. The reserved quota parliamentarians are disposed at the directives of the party politics. They are manipulated to vindicate the vested interests of the political parties. Having no constituency to represent, the minority and reserved quota parliamentarians have little why to engross in parliamentary processions. This political impedance has downright upset women's parliamentary participation further exacerbating the anterior aggravated situation.

\subsection{Patriarchal and Male-Dominant Politics}

The findings of the study show that the patriarchal model of politics and male dominance in parliament have dismally lowered the participation of women parliamentarians in parliamentary processions. Around the globe, figures infer that men enact an overall $81 \%$ of the parliamentary populace. In the political spheres, men are overrepresented outnumbering women populace. Besides, the patriarchal model and mindset of politics persist in our political structures. It is a socio-political structure that determines women as subservient to men adjudging them incapable of wielding liability and power. This portrayal of incompetency, unintelligence, subserviency and submissiveness has been hampering women's efficacy in political arena. Domestic labor and restrictions and regulations from males have also barred women's political endeavors.

Besides the alleged perception of submissiveness and incompetency, the scarce women populace in parliamentary rows find it hard to partake in parliamentary processions which has, in turn, downright subdued women's political profiles. The patriarchal-cum-prejudiced disposition and demeanor of the peers discourage and bar the political endeavors of women parliamentarians the impact of which echoes in a chain. Dejected over this elegiac political performance, the masses, in turn, resultantly, avoid patronizing women's candidature.

\subsection{Socio-Cultural Barriers and Non-Formal Institutions}

The findings of the study imply that socio-cultural taboos, expectation and norms are downright subduing the political participation of women parliamentarians in parliamentary processions. For a woman, going to the outdoor male dominant venues and partaking in the gendered political endeavors are all deemed culturally tabooed. Adopting their standards of demeanor according to the societal expectation upsets and interdicts the political endeavors of women parliamentarians. Besides, the combined segregation of male and female parliamentarians has also been questioned.

Besides, some informal-institutionary gatherings and efforts precede parliamentary sessions. Being arranged and held in the non-formal institutions like Hujra, Masjid, hotel, etc. religion and the sociocultural norms forbid the participation of women parliamentarians in these gatherings. Summarily, owing to the fact that they have to heed both their political profiles and societal expectation, women parliamentarians teeter about parliamentary political endeavors and the fulfillment of social codes of conduct.

\subsection{Poor Education and the Lack of Political Skills}

The findings of the study show that poor education and the lack of political astuteness hamper the effective participation of women parliamentarians in parliamentary processions. According to Ferris, Kolodinsky and Treadway (2007), "political skills are the ability to effectively understand others and use knowledge to influence others enhancing the achievement of objectives". Having strong political skills enables one to perform effectively valuing political profiles in turn. Parliamentary rhetoric, bills initiation, raising objections, questioning, moving resolutions, etc. require knowledge and strong political dexterity. The findings infer women parliamentarians' lack of education and political 
shrewdness upset their partaking in parliamentary sessions. As grave national issues are presented on the floor of the House, they require resourceful scholarship and political competency. This gap of scholarship and political proficiency prompts many parliamentarians to silencing and few to occupy the stage.

\section{Conclusion and Recommendation}

Inefficacious and scanty political participation of women parliamentarians is prevalent around the globe with varying obstacles behind. Women parliamentarians' role and participation is observed as less significant in comparison to their male peers. In the current study, women parliamentarians' experiences have been gauged to assess varying socio-political factors hampering their effective political performances. The findings of the study highlight some socio-political obstacles such as the lack of educational adeptness and political shrewdness, representing minority or reserved quota, the patriarchal and male-dominant mode of politics, party politics, impeding the effective participation of women parliamentarians. These findings are based upon the interviews of women parliamentarians and women's rights activists. All this has upset to work freely and securely dissuading women's political achievements. Benefitting from politics and the redressal of women-related issues, viz. gender discrimination, women illiteracy and violence against women, require women empowerment and maximal political participation. With the current outlook and demeanor towards women, modernization's tag would be unfit on our shoulders.

In the light of the findings of the study, the author recommends society changing its attitude towards women politics. Women participation in politics ought to be encouraged at the cost of the abolition of patriarchy. The government should help women parliamentarians. In order to be adept and astute, special trainings and sessions shall be arranged for women parliamentarians. Political parties should clearly policy in this regard avoiding party politics and the supremacy of some political figures.

\section{References}

Bano, S. (2009). Women in parliament in Pakistan; Problems and potential solutions. Women's Studies Journal, 23(1), 19.

Bibi, H. (2019). "Causes of Meager Participation of Women Parliamentarians in Khyber Pakhtunkhwa Assembly; and way out". Central Asia, 84(Summer), 125-136

Clarke, V., Braun, V., \& Hayfield, N. (2015). Thematic analysis. Qualitative psychology: A practical guide to research methods, 222-248.

Khan, A., \& Naqvi, S. (2020). Dilemmas of Representation: Women in Pakistan's Assemblies. Asian Affairs, 1-21.

Kolodinsky, R. W., Treadway, D. C., \& Ferris, G. R. (2007). "Political skill and influence effectiveness: Testing proportions of an expanded ferris and Judge (1991) model”. Human Relations 60, no. 12 (2007): 1747-1777.

Lawless, J. L., \& Fox, R. L. (2001). Political participation of the urban poor. Social problems, 48(3), 362-385.

Lodhi (2019). Challenges and issues to elected women parliamentarians to deliver effective parliamentary services: a case study of Punjab assembly', m. Phil Thesis, National University of Modern Languages, Islamabad.

Paxton, P.M., Hughes, M. M., \& Barnes, T. (2020). Women, politics, and power: A global perspective. Rowman \& Littlefield Publishers.

Teorell, J,. Torcal, M., \& Montero, J.R. (2007). 13 Political participation. Citizenship and involvement in European democracies: A comparative analysis, 334.

Union, I.P. (2016). Sexism, harassment and violence against women in parliaments in Europe.

Union, I.P. (2018). Sexism, harassment and violence against women in parliaments in Europe.

Zardari (2018). Empty women seats in parliament. The express Tribune. 